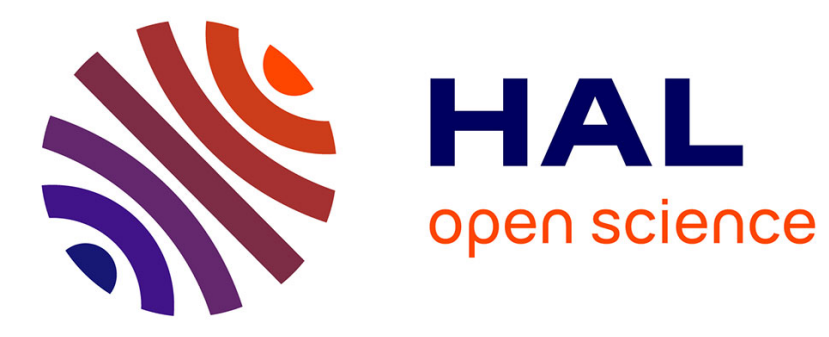

\title{
Impact of microstructure on anion exclusion in compacted clay media
}

Christophe Tournassat, Stéphane Gaboreau, Jean-Charles Robinet, Ian C. Bourg, Carl I. Steefel

\section{To cite this version:}

Christophe Tournassat, Stéphane Gaboreau, Jean-Charles Robinet, Ian C. Bourg, Carl I. Steefel. Impact of microstructure on anion exclusion in compacted clay media. Euroclay 2015, Clay Mineral Society, Jul 2015, Edinburgh, United Kingdom. hal-01137606

\section{HAL Id: hal-01137606 https: / hal-brgm.archives-ouvertes.fr/hal-01137606}

Submitted on 31 Mar 2015

HAL is a multi-disciplinary open access archive for the deposit and dissemination of scientific research documents, whether they are published or not. The documents may come from teaching and research institutions in France or abroad, or from public or private research centers.
L'archive ouverte pluridisciplinaire HAL, est destinée au dépôt et à la diffusion de documents scientifiques de niveau recherche, publiés ou non, émanant des établissements d'enseignement et de recherche français ou étrangers, des laboratoires publics ou privés. 


\title{
Impact of microstructure onanion exclusion in compacted clay media
}

Christophe Tournassat ${ }^{1,2^{*}}$, Stéphane Gaboreau ${ }^{1}$, Jean-Charles Robinet ${ }^{3}$, Ian C. Bourg ${ }^{4}$, Carl I. Steefel $^{2}$

${ }^{1}$ Water, Environment and Ecotechnology Division, French Geological Survey (BRGM), Orléans, 45060, France

${ }^{2}$ Earth Sciences Division, Lawrence Berkeley National Laboratory, Berkeley, CA 94720, United States

${ }^{3}$ Research and Development Division, Andra, Châtenay-Malabry, 92298, France

${ }^{4}$ Department of Civil and Environmental Engineering, Princeton University, Princeton, NJ 08544, United States

*Corresponding author: Christophe Tournassat, BRGM, D3E/SVP, 3 avenue Claude Guillemin, 45060 OrléansCedex 2, France. E-mail: c.tournassat@ brgm.

\begin{abstract}
The sensitivity of ion concentration distribution models to three key model assumptions, the pore-size distribution of clay media, the distance of closest approach of ions to the clay surface, and the accessibility of sub-nanometer-wide clay mineral interlayer spaces to anions, was explored by solving the Poisson-Boltzmann equation for swelling and non-swelling clay materials. Our calculations show that all three model assumptions significantly impact values predicted for the anion accessible porosity. As a consequence, macroscopic measurements of anion exclusion in clay media cannot be used to test any of the three model assumptions independently of the two others. Information gained at the nanoscale, in particular, a detailed characterization of pore size distribution, is necessary to develop accurate predictive models of the anion accessible porosity of clay media.
\end{abstract}

Keywords: clay, illite, montmorillonite, anion exclusion, Poisson-Boltzmann, microstructure, molecular dynamics. 